D. Palačić*

\title{
UTJECAJ PRIMJENE NORME OHSAS 18001 NA POBOLJŠANJE PERFORMANSI ZAŠTITE ZDRAVLJA I SIGURNOSTI NA RADU U HRVATSKOJ
}

UDK 006.85:331.45](497.5)

PRIMLJENO: 23.8 .2017$.

PRIHVAĆENO: 25.5.2018.

\begin{abstract}
SAŽETAK: Članak sadrži rezultate istraživanja utjecaja primjene zahtjeva norme OHSAS 18001 na poboljšanje performansi zaštite zdravlja i sigurnosti na radu u Hrvatskoj. Istraživanje je provedeno na utvrđenom uzorku metodom ankete pomoću pismenog upitnika. Anketa je po vrsti deskriptivno-analitička, a za ispitanike anonimna i dobrovoljna. Uzorak istraživanja su poslovne organizacije koje primjenjuju normu OHSAS 18001 u trajanju od najmanje tri godine. Cilj empirijskog istraživanja je utvrditi utjecaj primjene norme OHSAS 18001 na poboljšanje performansi zaštite zdravlja i sigurnosti na radu u poslovnim organizacijama koje primjenjuju navedenu normu. Osim osnovnih pokazatelja, performansama zaštite zdravlja i sigurnosti na radu smatra se i 124 zahtjeva norme OHSAS 18001. Zaključci istraživanja temelje se na provedenoj statističkoj analizi rezultata, pri čemu je primijenjena korelacijska i regresijska analiza.
\end{abstract}

Ključne riječi: OHSAS 18001, performanse, poboljšanje, zaštita zdravlja i sigurnost na radu

\section{UVOD}

Zaštita zdravlja i sigurnost na radu može se odrediti kao sustav tehničkih, zdravstvenih, pravnih, psiholoških, pedagoških i drugih aktivnosti, pomoću kojih se otkrivaju i otklanjaju opasnosti i štetnosti koje mogu ugroziti život i zdravlje osoba na radu. Zdravlje i sigurnost na radu predstavljaju neke od glavnih područja osobne sigurnosti za vrijeme izvođenja poslovnih procesa. Sigurnost na radu mora se promatrati kroz humane, ekonomske i socijalne aspekte koji pred poslodavce postavljaju zahtjeve za što bolje i učinkovitije upravljanje zaštitom zdravlja i sigurnošću na radu (Živković, Palačić, 2015.). Zbog negativnih statističkih pokazatelja trendova ozljeda na radu sa svim svojim značajkama,

*Dr. sc. Darko Palačić, (darko.palacic@vss.hr), Visoka škola za sigurnost, s pravom javnosti, Ivana Lučića 5, 10000 Zagreb, Hrvatska. znanstveno i stručno područje zaštite zdravlja i sigurnosti na radu kroz svoju afirmaciju je u neprestanom traganju za metodama i modelima povećanja učinkovitosti zaštite zdravlja i sigurnosti na radu u poslovnoj praksi.

Razvojem tehnologije i poslovnih procesa nastaju nove opasnosti i rizici kojima je potrebno upravljati novim metodama. U suvremenom poslovanju i upravljanju poslovnim procesima standardizacija svih postupaka, pa tako i postupaka povezanih sa zaštitom zdravlja i sigurnosti na radu, omogućuju stvaranje dodatne vrijednosti, konkurentnosti i uspješnosti u poslovanju organizacije. $U$ tom smislu primjena međunarodne norme za upravljanje zdravljem i sigurnošću na radu pridonosi razvoju novih modela upravljanja koji time postaju sastavni dio sveukupnog upravljanja poslovnom organizacijom. Značaj ovog područja sve više prepoznaju znanost $\mathrm{i}$ struka poslovnog upravljanja zbog čega u ovom 
segmentu postoji značajno povećanje praktične implementacije zahtjeva norme te se pokreću nova istraživanja (Palačić, 2016.).

Sustav upravljanja sigurnošću prema normi OHSAS 18001 je neprekidan, prilagodljiv proces koji se sastoji od niza povezanih aktivnosti, faza, elemenata i postupaka koji omogućava normalni tijek i funkcioniranje poslovnih procesa i sustava u koji moraju biti uključene sve osobe koje sudjeluju u poslovnim procesima organizacije ( $\mathrm{Pa}-$ lačić, 2011.). Stoga se može reći da je upravljanje sigurnošću jedan od složenijih i odgovornijih poslova u organizaciji, a koje zahtijeva puno aktivnosti, pozornosti i razmišljanja menadžmenta organizacije (Petersen, 2005.).

Mjerenje performansi zaštite zdravlja i sigurnosti na radu treba podrazumijevati količinu i kvalitetu djelovanja, kao i mjerenje neželjenih događaja (Powell, 2009.). Najčešće se kao performanse zaštite zdravlja i sigurnosti na radu mjere isključivo neželjeni događaji (ozljede, bolesti, smrtni slučajevi) sa svim njihovim karakteristikama kao što su izgubljeno radno vrijeme i ostali troškovi (Tarrants, 1980.), ali performanse sigurnosti zapravo su i mnoge druge značajke sigurnosti kao na primjer, planiranje, provedba ključnih aktivnosti (Arezes, Miguel, 2003.), sigurnosna kultura, upravljanje ljudskim resursima i slično (Živković, 2008.). Također, smatra se da primjena zahtjeva normi OHSAS 18001 i ISO 14001 može utjecati na poboljšanje kontroliranja u sustavu upravljanja sigurnošću (Živković, Palačić, Petras, 2008.). Učinkovitost sustava sigurnosti, odnosno sustava upravljanja sigurnošću, iznimno je važan.

Neki autori predlažu uspostavom trodijelne paradigme koja podrazumijeva pristup koji je moguće primijeniti i koristiti za razvijanje fleksibilnih planova za analizu postojećih sigurnosnih aspekata i programa. Paradigme takvog pristupa su analiza sigurnosne performanse (različiti načini kako bi učinkovito analizirale performanse), područja analize (specifični načini vrednovanja sustava upravljanja uključujući i organizacijske aspekte) te proces promjena (procesi tumačenja rezultata, izrade planova i provedbe promjena); (Petersen, 1996.).
Osnovni cilj upravljanja sigurnošću je smanjiti stupanj rizika od osnovnih opasnosti i prijetnji koje postoje u poslovnim procesima (Duijm i dr., 2008.). Upravljanje rizicima u sigurnosti je proces prepoznavanja, vrednovanja, tretiranja i nadzor nad mogućim pitanjima koja bi mogla utjecati na organizaciju.

Sigurnost je funkcija, organizacija, stanje i osjećaj koji omogućuju normalno funkcioniranje poslovnih sustava u kojem ne postoji narušavanje postojećeg stanja zbog različitih opasnosti i rizika (Hunjak, Palačić, Petričević, 2010.). Sustav upravljanja sigurnošću podrazumijeva utvrđivanje sustava odgovornosti, identifikacije rizika, te njihovo vrednovanje; drugim riječima, procjene rizika i upravljanje rizicima, izgradnju odgovarajućih sigurnosnih pravila i njihova primjena u stvarnom okruženju na temelju definirane politike sigurnosti.

Na osnovi provedenih istraživanja, Petersen (2001.) opisuje bitne elemente sigurnosnih programa koji se temelje na ponašanju zaposlenika. Uz to on uvodi novi model edukacije za sigurno ponašanje i izgradnju sigurnog radnog okruženja pomoću upravljanja ljudskim resursima u organizaciji. Autor zaključuje da postoje tri osnovna podsustava koje treba uzeti u obzir prilikom planiranja učinkovitog sustava upravljanja sigurnošću: fizički sustav, sustav kontrole i sustav ponašanja.

\section{NORMA OHSAS 18001:2007}

lako postoje brojne međunarodne norme za sustave upravljanja zdravljem i sigurnošću na radu, praksa pokazuje da se u Europi najviše primjenjuje sustav upravljanja zdravljem i sigurnošću na radu prema zahtjevima norme OHSAS 18001. Ova norma predstavlja osnovni alat za primjenu u području zaštite zdravlja i sigurnosti na radu. Primjena zahtjeva ove norme ima veliku vrijednost. To ne ukazuje samo na zabrinutost poslodavaca za zaposlenika, već ukazuje i na širu društvenu odgovornost. 
Norma OHSAS 18001 specificira zahtjeve za sustav upravljanja zaštitom zdravlja i sigurnošću na radu, a ima namjeru pomoći poslovnim sustavima u kontroli rizika zdravlja i sigurnosti na radu (British Standards Institution, 2007.). Navedena norma sa svojim zahtjevima promovira sigurnu i zdravu radnu okolinu tako što osigurava okvir koji tvrtkama dopušta da sustavno identificiraju i kontroliraju zdravstvene i sigurnosne rizike, smanjuju potencijalni rizik od ozljeda i nezgoda, da svoje sustave usklade sa zakonskim propisima te da poboljšanjem performansi u cijelosti poboljšaju svoje poslovanje.

Primjena norme OHSAS 18001 pomaže organizacijama u kontroli rizika zdravlja i sigurnosti na radu. Ona je industrijski normizacijski dokument za uvođenje i potvrđivanje sustava za upravljanje zdravljem i sigurnošću osoba na radu (Markič, 2003.). Sustav upravljanja zdravljem i sigurnošću na radu promovira sigurnu i zdravu radnu okolinu tako što osigurava okvir koji dopušta organizacijama da:

- sustavno identificiraju i kontroliraju svoje zdravstvene i sigurnosne rizike

- smanjuju potencijalni rizik od nezgoda

- svoje sustave usklade sa zakonskim propisima

- u cijelosti poboljšaju svoje poslovanje.

Osnovni ciljevi primjene OHSAS 18001 jesu:

- povećati sigurnost na radu u poslovnom sustavu

- poboljšati zdravstvenu zaštitu u poslovnom sustavu

- usklađivanje sa svim zakonskim propisima s područja sigurnosti na radu i zaštite zdravlja

- smanjiti postojeće i moguće rizike pri radu i ugrožavanje zdravlja

- povećati povjerenje radnika, korisnika proizvoda i usluga, poslovnih suradnika i društva isticanjem želje i volje da se djelotvornim mjerama poveća sigurnost na radu i zaštita zdravlja, uz istaknuto preventivno djelovanje
- smanjiti premije osiguranja (za djelatnosti koje nisu obuhvaćene zakonskim obvezama)

- povećati dobit smanjenjem mogućih gubitaka koji nastaju u slučaju nedovoljne brige i nestručnosti na području sigurnosti na radu i zaštite zdravlja radnika.

Smanjenje rizika i kontrola opasnosti ostvaruje se postavljanjem ciljeva, programa i dodijeljenih odgovornosti zaposlenicima. Kako bi se norma OHSAS 18001 mogla implementirati u bilo koju organizaciju, zahtjevi norme su pisani s tom namjerom. Stupanj primjene norme OHSAS 18001 ovisi o brojnim čimbenicima kao što su politika organizacije, priroda njezinih aktivnosti, te rizici i složenost radnih operacija. Norma OHSAS 18001 bavi se područjem zaštite zdravlja i sigurnosti na radu, ali pri tome ne zadire u druga područja zaštite zdravlja i sigurnosti kao što su sportski i ostali programi za poboljšanje stanja zaposlenih, zaštita proizvoda, imovine ili utjecaja na okoliš.

Norma OHSAS 18001 zasnovana je na procesnom pristupu, pa stoga zaštitu zdravlja i sigurnost na radu treba uključiti u osnovne operativne procedure. Iz navedenog proizlazi da je potrebno izgraditi procesno orijentiran sustav upravljanja zdravljem i sigurnošću na radu, pri čemu se provodi audit i daje ocjena svake pojedinačne lokacije.

Certifikacija primjene norme OHSAS 18001 dokazuje da sustav upravljanja unutar organizacije osigurava proaktivnu zaštitu zdravlja i sigurnosti na radu radnika te sukladnost sustava sa standardima najbolje prakse. Primjena norme OHSAS 18001 nije zakonski uvjetovana, ali je u nekim organizacijama neophodna. Posebno je to izraženo u organizacijama čije se djelatnosti smatraju visokorizičnima i gdje bez učinkovitog sustava zaštite zdravlja i sigurnosti na radu nije moguće osigurati radne uvjete koji ne bi predstavljali visok rizik za sigurnost. Također, neke organizacije uopće ne mogu sudjelovati na pojedinim tržištima ako ne primjenjuju zahtjeve norme OHSAS 18001 (Palačić, 2006.). 
Iskustva organizacija koje su implementirale sustav upravljanja zaštitom zdravlja i sigurnosti na radu prema zahtjevima ove norme pokazuju da učinkovitost sustava najviše ovisi o istinskoj opredijeljenosti uprave da uspostavi i održava sustav koji nadilazi zakonske zahtjeve. Također je kao značajna istaknuta učinkovita komunikacija koja uz aktivno uključivanje ključnih zaposlenika na različitim razinama u organizaciji (direktori, voditelji, poslovođe i ostali) utječe na stvaranje radnog okruženja u kojemu su svi zaposlenici svjesni svoje uloge i načina na koji mogu utjecati na vlastito zdravlje i sigurnost na radu, kao i svih ostalih osoba povezanih s radom.

Za očekivati je da će primjena norme OHSAS 18001 u poslovnim organizacijama utjecati na poboljšanje sljedećih performansi zaštite zdravlja i sigurnosti na radu:

- politika i ciljevi sustava upravljanja: jasno definirana politika i ciljevi (dugoročni i kratkoročni) zaštite zdravlja i sigurnosti na radu

- dokumentacija sustava upravljanja: programi, procedure, upute

- odlučivanje: donošenje odluka na osnovi statističkih analiza o ozljedama na radu, nezgodama na radu i bolestima u vezi s radom

- implementacija zahtjeva: primjena zahtjeva za sustav upravljanja

- ocjenjivanje sustava upravljanja: interno procjenjivanje sustava i ocjena uprave

- upravljanje rizicima: smanjiti postojeće i moguće rizike za zdravlje i sigurnost na radu

- upravljanje sigurnošću: povećati razinu zaštite zdravlja i sigurnosti na radu

- primjena zahtjeva propisa: uskladiti sustav sa zakonskim propisima iz područja zaštite zdravlja i sigurnosti na radu

- nezgode, ozljede, bolesti: smanjenje broja nezgoda, broja i težine ozljeda, bolesti u vezi s radom
- izvanredna stanja: organizirani i sustavni pristup u kriznim situacijama

- izgubljeni radni dani: smanjenje broja izgubljenih radnih dana zbog nezgoda, ozljeda i bolesti u vezi s radom

- materijalni troškovi: smanjenje direktnih i indirektnih financijskih troškova u području zaštite zdravlja i sigurnosti na radu, smanjenje operativnih troškova i gubitaka

- komunikacija i osvješćivanje: povećanje svijesti i povjerenja radnika, korisnika proizvoda ili usluga, poslovnih suradnika, društva, lokalne zajednice i javnih tijela

- isticanje želje i volje da se djelotvornim mjerama poveća zaštita zdravlja i sigurnosti na radu uz istaknuto preventivno djelovanje

- osiguranje: smanjenje premije osiguranja

- tržište: omogućavanje pristupa tržištima koje kao uvjet imaju primjenu zahtjeva OHSAS 18001

- imidž poslovne organizacije: poboljšanje imidža poslovne organizacije u okolini (Palačić, 2017.).

\section{METODOLOGIJA ISTRAŽIVANJA}

\section{Svrha istraživanja}

Na osnovi analize ranije provedenih istraživanja utvrđen je istraživački problem nedostatka aktualnih spoznaja o povezanosti primjene zahtjeva norme OHSAS 18001 s poboljšanjem performansi zaštite zdravlja i sigurnosti na radu u poslovnim organizacijama u Hrvatskoj.

\section{Cilj istraživanja}

S obzirom na prepoznati istraživački problem, cilj istraživanja je utvrditi utjecaj primjene zahtjeva norme OHSAS 18001 na poboljšanje performansi zaštite zdravlja i sigurnosti na radu. Cilj istraživanja ima dva osnovna aspekta. Prvi aspekt istraživanja je teorijskog karaktera i podrazumijeva teorijsko razmatranje i analizu svih čimbenika i okolnosti koji determiniraju potrebu primjene upravljanja zaštitom zdravlja i sigurno- 
šću na radu općenito i primjenu zahtjeva norme OHSAS 18001 kao sastavnog dijela suvremenog poslovnog pristupa upravljanju poslovnim sustavima. Empirijskim istraživanjem, koje predstavlja drugi aspekt istraživanja, utvrdit će se utjecaj primjene zahtjeva norme OHSAS 18001 na poboljšanje performansi zaštite zdravlja i sigurnosti na radu u poslovnim organizacijama koji primjenjuju navedene zahtjeve tri ili više godina.

\section{Zadaci istraživanja}

U skladu s postavljenim ciljem zadaci istraživanja su:

- istražiti i analizirati teorijske osnove područja upravljanja zaštitom zdravlja i sigurnošću na radu

- istražiti i analizirati sustav upravljanja zaštitom zdravlja i sigurnošću na radu prema OHSAS 18001

- analizirati zahtjeve norme OHSAS 18001

- ispitati i prikazati rezultate istraživanja utjecaja primjene zahtjeva norme OHSAS 18001 na poboljšanje performansi zaštite zdravlja i sigurnosti na radu

- utvrditi povezanost primjene norme OHSAS 18001 s poboljšanjem performansi zaštite zdravlja i sigurnosti na radu.

\section{Hipoteze}

Kao temelj postavljena je opća hipoteza:

$\mathrm{H}_{0}$ : Postoji povezanost između primjene zahtjeva norme OHSAS 18001 i performansi zaštite zdravlja i sigurnosti na radu. Primjenom zahtjeva norme OHSAS 18001 mogu se poboljšati performanse zaštite zdravlja i sigurnosti na radu.

Iz opće hipoteze izvedene su sljedeće posebne hipoteze:

$\mathrm{H}_{1}$ : Postoji povezanost između primjene zahtjeva norme OHSAS 18001 i broja ozljeda na radu i profesionalnih bolesti.

$\mathrm{H}_{2}$ : Postoji povezanost između primjene zahtjeva norme OHSAS 18001 i investicija u zaštiti zdravlja i sigurnosti na radu.
$\mathrm{H}_{3}$ : Postoji povezanost između primjene zahtjeva norme OHSAS 18001 i poboljšanja planiranja sustava zaštite zdravlja i sigurnosti na radu.

$\mathrm{H}_{4}$ : Postoji povezanost između primjene zahtjeva norme OHSAS 18001 i poboljšanja u području uvođenja i provedbe sustava zaštite zdravlja i sigurnosti na radu.

$\mathrm{H}_{5}$ : Postoji povezanost između primjene zahtjeva norme OHSAS 18001 i poboljšanja provjeravanja i korektivnih aktivnosti u sustavu zaštite zdravlja i sigurnosti na radu.

$\mathrm{H}_{6}$ : Postoji povezanost između primjene zahtjeva norme OHSAS 18001 i ocjenjivanja sustava zaštite zdravlja i sigurnosti na radu.

Za potrebe anketnog istraživanja i koncipiranja anketnog upitnika kao instrumenta anketnog istraživanja, a u skladu s postavljenim ciljem i hipotezama istraživanja utvrđene su varijable anketnog istraživanja prikazane u Tablici 1.

\section{Tablica 1. Nezavisne i zavisne varijable}

Table 1. Independent and dependent variables

\begin{tabular}{||l|l||}
\hline Nezavisne varijable & Zavisne varijable \\
\hline 1. Profil organizacije & 1. Performanse zaštite \\
2dravlja i sigurnosti na \\
2. Profil stručnjaka-ispitanika \\
3. Osnovni podaci o zaštiti \\
zdravlja i sigurnosti na radu \\
$\begin{array}{l}\text { u poslovnoj organizaciji } \\
\text { 4. Podaci o sustavima za } \\
\text { upravljanje sigurnošću na } \\
\text { radu }\end{array}$ \\
\hline
\end{tabular}

\section{Metoda istraživanja}

$\cup$ empirijskom dijelu istraživanja koristi se metoda ankete. Anketa je po vrsti deskriptivno-analitička, a za ispitanike anonimna i dobrovoljna. Kao priprema za određivanje anketnih pitanja izvršena je identifikacija i dekompozicija problema te su određeni faktori rješenja. Utvrđeni su elementi koji se mjere i način mjerenja. Anketiranjem se utvrđuje prošlo i postojeće stanje, te subjektivno mišljenje i ocjene ispitanika. Anketno istraživanje provedeno je pismeno anketom, putem elektroničke pošte. Podaci su obrađeni na način koji osigurava anonimnost ispitanika. 


\section{Statističke metode}

Za statističku analizu rezultata istraživanja korišteni su sljedeći statistički pokazatelji i metode: frekvencija $(\mathrm{f})$, postotak $(\%)$, suma $(\Sigma)$, aritmetička sredina (M), standardna devijacija populacije $(s)$, te koeficijent varijabilnosti populacije (V) izražen u postocima (\%), kurtosis, skewness, hi-kvadrat testom $(\chi 2)$ - za testiranje statičke značajnosti razlika među određenim rezultatima, Pearsonov koeficijent korelacije (r) - za testiranje povezanosti između utvrđenih zavisnih i nezavisnih varijabli istraživanja, višestruka regresijska analiza - za testiranje povezanosti između utvrđenih zavisnih i nezavisnih varijabli istraživanja, uz postavljanje standardnog oblika modela višestruke linearne regresije s jednom zavisnom varijabli (Y) i više (k) nezavisnih varijabli $(X)$.

\section{Uzorak}

Ukupnu populaciju istraživanja čine poslovne organizacije u Republici Hrvatskoj koje primjenjuju zahtjeve norme OHSAS 18001 u trajanju najmanje tri godine, kojih je prema dostupnim podacima u trenutku istraživanja bilo ukupno 95. Iz osnovnog skupa odabran je jednostavni slučajni uzorak za koji je karakteristično da sve jedinice iz osnovnog skupa imaju jednaku mogućnost da budu izabrane u uzorak. Slučajni uzorak određuje se pomoću tablice slučajnih brojeva (Žugaj, Dumičić, Dušak, 1999.). Pri određivanju uzorka primijenjena je metoda izbora uzorka bez ponavljanja, odnosno elementi za uzorak odabrani su redom, a isti su nakon izbora ostali u osnovnom skupu i time sudjelovali u izboru sljedećeg elementa za uzorak. Veličina uzorka zasniva se na dvije prosudbene odluke: razini pouzdanosti i dopuštenoj grešci uzorkovanja. Kako se u istraživanju radi o zaštiti zdravlja i sigurnosti na radu, određen je koeficijent povjerenja 1,28 koji je zadan odabranom vjerojatnosti procjene od $80 \%$, uz dopuštenu grešku od $\pm 10 \%$ i koeficijent varijacije populacije $50 \%$. Određena veličina jednostavnog slučajnog uzorka $(n=41)$ predstavlja ukupan broj poduzeća (jedinica uzorka) koji se uključuju u anketno istraživanje. Uzorak je reprezentativan i probabilistički. Reprezentativnost uzorka postiže se ispravnim slučajnim izborom elemenata osnovnog skupa, osnovnim karakteristikama tih elemenata, razinom pouzdanosti i dopuštenom greškom. Uzorak predstavlja umanjenu sliku osnovnog skupa.

Kvalitativna i kvantitativna analiza rezultata istraživanja sadrži srednje vrijednosti ocjena svih promatranih indikatora pojedinačno, te $u$ grupama, kao i međusobnu usporedbu pojedinih rezultata. Dobiveni odgovori obrađeni su pomoću programa IBM SPSS Statistics (Statistical Package for the Social Sciences). Od ukupnog broja poslanih anketnih upitnika (41 jedinica uzorka) vraćeno je 37 ispravno ispunjenih upitnika što čini odgovor na anketu od 90,24\%. Relativno gledajući, istraživanjem je bilo obuhvaćeno $38,94 \%$ osnovnog skupa.

\section{KARAKTERISTIKE UZORKA ISTRAŽIVANJA}

Prema pravnom statusu 59,46 \% registrirano je kao društvo s ograničenom odgovornošću, $35,14 \%$ dioničko društvo, a 5,41 \% kao ostali oblici pravnog statusa.

Od navedenog broja poslovnih organizacija $62,16 \%$ ih je u privatnom domaćem vlasništvu, $27,03 \%$ u privatnom stranom vlasništvu, a po $5,41 \%$ ih je u privatnom domaćem i stranom vlasništvu te u mješovitom javnom i privatnom vlasništvu.

Što se tiče glavne djelatnosti poslovne organizacije, 48,65 \% poslovnih organizacija ubraja se u prerađivačku industriju, nakon čega s udjelom od 16,22 \% slijedi građevinarstvo, 10,81\% rudarstvo i vađenje, 8,11 \% ostale uslužne djelatnosti, itd.

Prema spolu u istraživanju je sudjelovalo $73 \%$ ispitanika muškog spola i $27 \%$ ispitanica ženskog spola. S obzirom na dobnu skupinu ispitanika, 40,54 \% ispitanika nalazi se u dobnoj skupini od 31 do 40 godina, 29,73\% u skupini 
od 41 do 50 godina, $21,62 \%$ od 51 do 60 godina, dok je 8,11\% ispitanika u skupini do 30 godina života. Po 29,73 \% ispitanika ukupni radni staž ima u trajanju od 6 do 10 godina te od 21 do 30 godina, 24,32\% ispitanika u trajanju od 11 do 20 godina, a po 8,11 \% ispitanika ukupni staž ima u trajanju od 3 do 5 godina te više od 30 godina. Ukupno $37,84 \%$ ispitanika radni staž na poslovima sigurnosti ima u trajanju od 6 do 10 godina, 29,73\% u trajanju od 11 do 20 godina, 27,03\% u trajanju od 3 do 5 godina, a po $2,70 \%$ ispitanika radni staž na poslovima sigurnosti ima u trajanju do 2 godine te više od 30 godina.

\section{REZULTATI I RASPRAVA}

Nakon primjene deskriptivne statistike te analitičkih statističkih metoda opisane su osnovne značajke uzorka istraživanja te su pojašnjeni dobiveni rezultati. Dobiveni podaci o subjektivnim mišljenjima i ocjenama (intenzitetu) ispitanika obrađeni su metodama analitičke statistike koje omogućuju da se na osnovi podataka iz uzorka zaključuje o karakteristikama cijele populacije. Nakon navedenog se pristupilo statističkoj analizi i obradi prikupljenih podataka primjenom inferencijalne (analitičke) statistike. Namjera ovog postupka je da se statističkom analizom i određenim statističkim metodama pokušaju dokazati neke ili sve polazne hipoteze koje su postavljene prije započetog istraživanja.

$\mathrm{H}_{0}$ : Postoji povezanost između primjene zahtjeva norme OHSAS 18001 i performansi zaštite zdravlja i sigurnosti na radu. Primjenom zahtjeva norme OHSAS 18001 mogu se poboljšati performanse zaštite zdravlja i sigurnosti na radu

Opća hipoteza $\left(\mathrm{H}_{0}\right)$ - Postoji povezanost između primjene zahtjeva norme OHSAS 18001 i performansi zaštite zdravlja i sigurnosti na radu se prihvaća. Nakon računanja svih vrijednosti koje su dobivene primjenom deskriptivnih i inferencijskih statističkih metoda utvrđen je Pearsonov koeficijent korelacije za varijable koje su u linearnom odnosu, te regresijska analiza jedne zavisne varijable od jedne ili više nezavisnih varijabli s ciljem da se utvrdi analitički izraz takve povezanosti. Pri tome je utvrđena povezanost primjene zahtjeva norme OHSAS 18001 i performansi zaštite zdravlja i sigurnosti na radu pa se zaključuje da se primjenom zahtjeva norme OHSAS 18001 mogu poboljšati performanse zaštite zdravlja i sigurnosti na radu.

$\mathbf{H}_{1}$ : Postoji povezanost između primjene zahtjeva norme OHSAS 18001 i broja ozljeda na radu i profesionalnih bolesti

$U$ promatranom razdoblju prve tri godine od početka primjene zahtjeva norme u svim je organizacijama evidentirano smanjenje broja nezgoda na radu, ozljeda na radu i poginulih na radu, dok profesionalne bolesti nisu evidentirane. Navedeni pokazatelji predstavljaju osnovne performanse zaštite zdravlja i sigurnosti na radu. Tijekom navedenog razdoblja prosječno je za $57,18 \%$ smanjen broj nezgoda na radu, za $64,91 \%$ broj ozljeda na radu, a za $100 \%$ broj poginulih na radu.

Tablica 2. Broj nezgoda, ozljeda na radu, smrtnih slučajeva i profesionalnih bolesti

Table 2. Number of accidents, injuries at work, deaths, and occupational diseases

\begin{tabular}{||l|c|c|c||}
\hline $\begin{array}{l}\text { Broj nezgoda, ozljeda } \\
\text { na radu, smrtnih } \\
\text { slučajeva i profesio- } \\
\text { nalnih bolesti }\end{array}$ & $\begin{array}{c}\mathbf{1 .} \\
\text { godina }\end{array}$ & $\begin{array}{c}\mathbf{2 .} \\
\text { godina }\end{array}$ & $\begin{array}{c}\mathbf{3 .} \\
\text { godina }\end{array}$ \\
\hline broj nezgoda na radu & 675 & 540 & 289 \\
\hline broj ozljeda na radu & 1046 & 682 & 367 \\
\hline $\begin{array}{l}\text { broj poginulih na } \\
\text { radu }\end{array}$ & 1 & 0 & 0 \\
\hline
\end{tabular}

Korelacijska analiza pokazuje vrlo dobru ili odličnu pozitivnu međusobnu povezanost broja nezgoda na radu i ozljeda na radu u poduzeću. Može se konstatirati da broj nezgoda i ozljeda na radu u poduzeću utječe na smanjenje broja nezgoda i ozljeda na radu u poduzeću u narednoj godini.

Broj ozljeda na radu je u slaboj $(r=0,26-0,50)$ negativnoj korelaciji $s$ određenim zahtjevima norme. $U$ negativnoj slaboj korelaciji s brojem ozljeda na radu je ukupno 36 zahtjeva standarda. Broj ozljeda na radu je u umjerenoj do dobroj $(r=0,51-0,71)$ negativnoj povezanosti sa za- 
htjevima norme „istraživanje incidenata provodi se pravodobno". Negativna korelacija podrazumijeva međusobnu povezanost na način da što je bolje ocijenjena primjena zahtjeva norme to je manji broj ozljeda na radu, čime se dokazuje da bolja primjena tog zahtjeva više utječe na smanjenje broja ozljeda na radu.

Prema navedenome, za ukupno 37 zahtjeva $(30,08 \%$ od ukupnog broja zahtjeva) norme utvrđeno je da njihova primjena utječe na smanjenje broja ozljeda na radu. Pregledom zahtjeva koji su povezani s brojem ozljeda na radu može se konstatirati da se radi o operativnim zahtjevima koji nisu samo administrativni postupci. Nakon provedene analize korelacije broja ozljeda na radu i primjene područja upravljanja za sve tri godine primjene utvrđena je slaba negativna povezanost broja ozljeda na radu i primjene zahtjeva u vezi s primjenom i provedbom (u rasponu od -0,365 do -0,463). Može se konstatirati da najvažniji operativni zahtjevi norme koji se nalaze u području upravljanja u vezi s primjenom i provedbom utječu na smanjenje broja ozljeda na radu.

S obzirom da u razdoblju provedbe istraživanja nije bilo evidentiranih profesionalnih bolesti, nije moguće utvrditi povezanost primjene zahtjeva norme OHSAS 18001 i broja profesionalnih bolesti.

Hipoteza $\left(\mathrm{H}_{1}\right)$ - Postoji povezanost između primjene zahtjeva norme OHSAS 18001 i broja ozljeda na radu i profesionalnih bolesti djelomično se prihvaća. Provedenom statističkom analizom dokazana je povezanost broja ozljeda na radu i profesionalnih bolesti. S obzirom da profesionalne bolesti nisu evidentirane, nije bilo moguće utvrditi statističku povezanost primjene zahtjeva norme s brojem profesionalnih bolesti.

\section{$\mathrm{H}_{2}$ : Postoji povezanost između primjene zahtjeva norme OHSAS 18001 i investicija u zaštitu zdravlja i sigurnost na radu}

U organizaciji iz uzorka istraživanja koja je imala najmanji godišnji prihod ukupne investicije u zaštitu zdravlja i sigurnost na radu u promatranom razdoblju padale su od 0,35 \% do 0,22 \% ukupnog godišnjeg prihoda poduzeća. U organizaciji iz uzorka istraživanja koja je imala najveći godišnji prihod ukupne investicije u zaštitu zdravlja i sigurnost na radu u promatranom razdoblju porasle su od 0,29 \% do 0,42 \% ukupnog godišnjeg prihoda poduzeća. Prosječne ukupne investicije u zaštitu zdravlja i sigurnost na radu u razdoblju prve tri godine od početka primjene zahtjeva norme OHSAS 18001 porasle su od $0,13 \%$ na $0,17 \%$ prosječnog ukupnog godišnjeg prihoda poduzeća iz uzorka istraživanja.

Investicije u zaštitu zdravlja i sigurnost na radu su u slaboj $(r=0,26-0,50)$ pozitivnoj korelaciji s određenim zahtjevima norme. U pozitivnoj slaboj korelaciji s investicijama u zaštitu zdravlja i sigurnost na radu je ukupno 36 zahtjeva norme. Investicije u zaštitu zdravlja i sigurnost na radu su u dobroj $(r=0,51-0,75)$ pozitivnoj korelaciji s određenim zahtjevima norme. U pozitivnoj dobroj korelaciji s investicijama u zaštitu zdravlja i sigurnost na radu je ukupno 9 zahtjeva norme. Pozitivna korelacija podrazumijeva međusobnu povezanost na način da što je veća investicija, to je bolje ocijenjena primjena zahtjeva norme, čime se dokazuje da veća investicija utječe na bolju primjenu nekog zahtjeva norme. Investicije u zaštitu zdravlja i sigurnost na radu su u odličnoj $(r=0,76-1)$ povezanosti sa zahtjevima norme „korektivne i preventivne mjere preispitane su u smislu prikladnosti i učinkovitosti". 
Tablica 3. Investicije u zaštitu zdravlja i sigurnost na radu

Table 3. Investments in health and safety at work

\begin{tabular}{|c|c|c|c|c|c|c|c|}
\hline \multirow{2}{*}{\multicolumn{2}{|c|}{ Financijski pokazatelji }} & \multicolumn{2}{|c|}{ 1. godina } & \multicolumn{2}{|c|}{ 2. godina } & \multicolumn{2}{|c|}{ 3. godina } \\
\hline & & $f(€)$ & $\%$ & $f(€)$ & $\%$ & $f(€)$ & $\%$ \\
\hline $\begin{array}{l}\text { ukupne investicije u zaštitu } \\
\text { zdravlja i sigurnost na radu }\end{array}$ & \multirow{2}{*}{ MIN } & $2.000,00$ & $0,35 \%$ & $2.500,00$ & $1,68 \%$ & $1.500,00$ & $0,22 \%$ \\
\hline $\begin{array}{l}\text { ukupan godišnji prihod orga- } \\
\text { nizacije }\end{array}$ & & $576.960,00$ & & $149.021,00$ & & $674.100,00$ & \\
\hline $\begin{array}{l}\text { ukupne investicije u zaštitu } \\
\text { zdravlja i sigurnost na radu }\end{array}$ & \multirow{2}{*}{ MAX } & $330.000,00$ & $0,29 \%$ & $350.000,00$ & $0,29 \%$ & $500.000,00$ & $0,42 \%$ \\
\hline $\begin{array}{l}\text { ukupan godišnji prihod orga- } \\
\text { nizacije }\end{array}$ & & $115.340 .700,00$ & & $119.157 .850,00$ & & $118.560 .450,00$ & \\
\hline $\begin{array}{l}\text { ukupne investicije u zaštitu } \\
\text { zdravlja i sigurnost na radu }\end{array}$ & \multirow{2}{*}{ M } & $23.173,51$ & $0,13 \%$ & $26.059,73$ & $0,15 \%$ & $31.696,89$ & $0,17 \%$ \\
\hline $\begin{array}{l}\text { ukupan godišnji prihod orga- } \\
\text { nizacije }\end{array}$ & & $17.646 .199,81$ & & $17.955 .764,32$ & & $18.420 .177,92$ & \\
\hline
\end{tabular}

Prema navedenome, za ukupno 46 zahtjeva $(37,39 \%$ od ukupnog broja zahtjeva) norme utvrđeno je da je njihova primjena povezana s investicijama u zaštitu zdravlja i sigurnost na radu. Ovo upućuje na zaključak da investicije pozitivno utječu na poboljšanje performansi zaštite zdravlja i sigurnosti na radu.

Hipoteza $\left(\mathrm{H}_{2}\right)$ - Postoji povezanost između primjene zahtjeva norme OHSAS 18001 i investicija u zaštitu zdravlja i sigurnost na radu se prihvaća. Analizom podataka za tri godine primjene norme dokazana je povezanost s povećanjem investicija u zaštitu zdravlja i sigurnost na radu.

$\mathrm{H}_{3}$ : Postoji povezanost između primjene zahtjeva norme OHSAS 18001 i poboljšanja planiranja sustava zaštite zdravlja $i$ sigurnosti na radu

U skupini od 35 pitanja u vezi s planiranjem zaštite zdravlja i sigurnosti na radu ispitanici su se izjašnjavali o primjeni navedenih zahtjevima norme kojima se poboljšavaju operativne performanse planiranja. Time su se utvrdili podaci o primjeni ovih zahtjeva norme i poboljšanju performansi u vezi s planiranjem zaštite zdravlja i sigurnosti na radu u poduzećima u prve 3 godine njihove primjene. Svi zahtjevi norme primjenjuju se, a njihova primjena ocijenjena je u rasponu prosječnih ocjena od 2,7 do 4,92.
Najnižom prosječnom ocjenom 2,7 ocijenjena je tvrdnja "odgovornosti i ovlasti za postizanje ciljeva dodijeljene su za upravljanje programima svakoj odgovarajućoj funkciji i razini", i to u prvoj godini primjene norme. Najvišom prosječnom ocjenom 4,92 u trećoj godini primjene norme ocijenjene su tvrdnje „ciljevi su dokumentirani" i "ciljevi uključuju obvezu kontinuiranog poboljšanja“. Za svaki zahtjev norme utvrđen je rast prosječne ocjene njegove primjene, čime se zaključuje da primjena zahtjeva norme utječe na poboljšanje performansi zaštite zdravlja i sigurnosti na radu.

Ovisno o godini primjene zahtjeva, standardna devijacija prosječno se kreće u rasponu od 0,277 do 1. Koeficijent varijabilnosti populacije prema godinama primjene kreće se u rasponu od 0,12 do $1 \%$. Provedenim $\chi^{2}$ testom utvrđeno je da je razlika između frekvencija ocjena primjene zahtjeva u vezi s planiranjem statistički značajna, odnosno nije slučajna. Vjerojatnost slučajne pojave ovakvih rezultata manja je od $1 \%$ (a kod nekih rezultata manja je od $0,1 \%$ ). Na temelju tih rezultata mogu se donositi statistički valjani zaključci.

Analizom ocjena tvrdnji za tri godine primjene sustava upravljanja utvrđeno je da se u ukupno 32 slučaja ocjena tvrdnji u vezi s planiranjem zaštite zdravlja i sigurnosti na radu radi o odličnoj korelaciji varijabli (u rasponu od 
$0,76$ do 1$)$. Analizom ocjena tvrdnji za tri godine primjene sustava upravljanja utvrđeno je da se u ukupno 592 slučaja ocjena tvrdnji u vezi s planiranjem radi o dobroj korelaciji varijabli. Visina korelacije u navedenim slučajevima iznosi od 0,51 do 0,75. U ukupno 1336 slučajeva ocjena tvrdnji u rasponu je od 0,25 do 0,50 što potvrđuje da se radi o slaboj korelaciji varijabli u vezi s planiranjem. $U$ ostalim slučajevima nije utvrđena korelacija navedenih varijabli. Iz svega navedenog može se zaključiti da postoji povezanost između primjene zahtjeva norme OHSAS 18001 i poboljšanja planiranja zaštite zdravlja i sigurnosti na radu.

Hipoteza $\left(\mathrm{H}_{3}\right)$ - Postoji povezanost između primjene zahtjeva norme OHSAS 18001 i poboljšanja planiranja sustava zaštite zdravlja i sigurnosti na radu se prihvaća. Nakon provedene statističke analize za sve zahtjeve norme u vezi s područjem planiranja zaštite zdravlja i sigurnosti na radu utvrđen je rast prosječne ocjene tijekom tri godine primjene, čime se zaključuje da primjena zahtjeva standarda utječe na poboljšanje navedenog područja upravljanja.

\section{$\mathrm{H}_{4}$ : Postoji povezanost između primjene zahtjeva norme OHSAS 18001 i poboljšanja u području uvođenja i provedbe sustava zaštite zdravlja i sigurnosti na radu}

U skupini od 46 pitanja u vezi s uvođenjem i provedbom zaštite zdravlja i sigurnosti na radu ispitanici su se izjašnjavali o primjeni navedenih zahtjevima norme kojima se poboljšavaju operativne performanse uvođenja i provedbe. Time su utvrđeni podaci o primjeni ovih zahtjeva norme i poboljšanju performansi u vezi s uvođenjem i provedbom zaštite zdravlja i sigurnosti na radu u poduzećima u prve 3 godine njihove primjene. Svi zahtjevi norme primjenjuju se, a njihova je primjena ocijenjena u rasponu prosječnih ocjena od 2,89 do 4,89. Najnižom prosječnom ocjenom 2,89 ocijenjena je tvrdnja „primjenjuju se postupci komuniciranja relevantnih procedura i/ili zahtjeva, o opasnostima povezanim s kupljenim proizvodima, opremi i uslugama prema dobavljačima i izvođačima", i to u prvoj godini primjene norme. Najvišom prosječnom ocjenom
4,89 u trećoj godini primjene norme ocijenjena je tvrdnja „provedene su procedure za prepoznavanje potencijalnih incidenata, nesreća i izvanrednih stanja s potencijalnim utjecajem". Za svaki zahtjev norme utvrđen je rast prosječne ocjene njegove primjene, čime se zaključuje da primjena zahtjeva standarda utječe na poboljšanje performansi zaštite zdravlja i sigurnosti na radu.

Ovisno o godini primjene zahtjeva, standardna devijacija prosječno se kreće u rasponu od 0,229 do 0,987. Koeficijent varijabilnosti populacije prema godinama primjene kreće se u rasponu od 0,099 do 0,886 \%. Provedenim $\chi^{2}$ testom utvrđeno je da je razlika između frekvencija ocjena primjene zahtjeva u vezi s uvođenjem i provedbom statistički značajna, odnosno nije slučajna. Vjerojatnost slučajne pojave ovakvih rezultata manja je od $1 \%$ (a kod nekih rezultata manja je od 0,1\%). Na temelju tih rezultata mogu se donositi statistički valjani zaključci.

Analizom ocjena tvrdnji za tri godine primjene sustava upravljanja utvrđeno je da se u ukupno 95 slučaja ocjena tvrdnji u vezi s uvođenjem i provedbom zaštite zdravlja i sigurnosti na radu radi o odličnoj korelaciji varijabli (u rasponu od 0,76 do 1). Nadalje, analizom ocjena tvrdnji utvrđeno je da se u ukupno 1106 slučajeva ocjena tvrdnji u vezi s uvođenjem i provedbom radi o dobroj korelaciji varijabli. Visina korelacije u navedenim slučajevima iznosi od 0,51 do 0,75. U ukupno 2239 slučajeva ocjena tvrdnji u vezi s uvođenjem i provedbom u rasponu je od 0,25 do 0,50 što potvrđuje da se radi o slaboj korelaciji varijabli povezanih s primjenom i provedbom. U ostalim slučajevima nije utvrđena korelacija navedenih varijabli. Na temelju prikazanih rezultata može se zaključiti da postoji povezanost između primjene zahtjeva norme OHSAS 18001 i poboljšanja u području uvođenja i provedbe zaštite zdravlja i sigurnosti na radu.

Hipoteza $\left(\mathrm{H}_{4}\right)$ - Postoji povezanost između primjene zahtjeva norme OHSAS 18001 i poboljšanja u području uvođenja i provedbe sustava zaštite zdravlja i sigurnosti na radu se prihvaća. Provedenom statističkom analizom za sve 
zahtjeve norme u vezi s područjem uvođenja i provedbom zaštite zdravlja i sigurnosti na radu utvrđen je rast prosječne ocjene tijekom tri godine primjene, čime se zaključuje da primjena zahtjeva norme utječe na poboljšanje navedenog područja upravljanja sustavom.

\section{$\mathrm{H}_{5}$ : Postoji povezanost između primjene zahtjeva norme OHSAS 18001 i poboljšanja provjeravanja i korektivnih aktivnosti u sustavu zaštite zdravlja i sigurnosti na radu}

U skupini od 26 pitanja u vezi s provjeravanjem i korektivnom aktivnosti zaštite zdravlja i sigurnosti na radu ispitanici su se izjašnjavali o primjeni navedenih zahtjevima norme kojima se poboljšava provjera i korektivnim aktivnostima. Time su utvrđeni podaci o primjeni ovih zahtjeva norme i poboljšanju performansi u vezi s provjerom i korektivnim aktivnostima zaštite zdravlja i sigurnosti na radu u poduzećima u prve 3 godine njihove primjene. Svi zahtjevi norme primjenjuju se, a njihova primjena ocijenjena je $u$ rasponu prosječnih ocjena od 3,05 do 4,84. Najnižom prosječnom ocjenom 3,05 ocijenjena je tvrdnja "korektivne i preventivne mjere preispitane su u smislu prikladnosti i učinkovitosti“, i to u prvoj godini primjene norme. Najvišom prosječnom ocjenom 4,84 u trećoj godini primjene norme ocijenjena je tvrdnja "postupci audita razvijeni su i provedeni u planiranim intervalima". Prema prikazanim rezultatima za svaki zahtjev norme utvrđen je rast prosječne ocjene njegove primjene, čime se zaključuje da primjena zahtjeva norme utječe na poboljšanje performansi zaštite zdravlja i sigurnosti na radu.

Ovisno o godini primjene zahtjeva, standardna devijacija prosječno se kreće u rasponu od 0,229 do 1,096. Koeficijent varijabilnosti populacije prema godinama primjene kreće se u rasponu od 0 do $1,201 \%$. Provedenim $\chi^{2}$ testom utvrđeno je da je razlika između frekvencija ocjena primjene zahtjeva u vezi s provjerom i korektivnim aktivnostima statistički značajna, odnosno nije slučajna. Vjerojatnost slučajne pojave ovakvih rezultata manja je od $1 \%$ (a kod nekih rezultata manja je od 0,1\%). Na temelju tih rezultata mogu se donositi statistički valjani zaključci.
Analizom ocjena tvrdnji za tri godine primjene sustava upravljanja utvrđeno je da se u ukupno 154 slučaja ocjena tvrdnji u vezi s provjeravanjem i korektivnim aktivnostima radi o odličnoj korelaciji varijabli (u rasponu od 0,76 do 1). Nadalje, analizom ocjena tvrdnji utvrđeno je da se u ukupno 708 slučajeva ocjena tvrdnji u vezi s provjeravanjem i korektivnim aktivnostima radi o dobroj korelaciji varijabli. Visina korelacije u navedenim slučajevima iznosi od 0,51 do 0,75. U ukupno 822 slučaja ocjena tvrdnji u vezi s provjeravanjem i korektivnim aktivnostima u rasponu je od 0,25 do 0,50 što potvrđuje da se radi o slaboj korelaciji varijabli u vezi s provjeravanjem i korektivnim aktivnostima. U ostalim slučajevima nije utvrđena korelacija navedenih varijabli. Prema prikazanim rezultatima može se zaključiti da postoji povezanost između primjene zahtjeva norme OHSAS 18001 i poboljšanja provjeravanja i korektivnih aktivnosti u zaštiti zdravlja i sigurnosti na radu.

Hipoteza $\left(\mathrm{H}_{5}\right)$ - Postoji povezanost između primjene zahtjeva norme OHSAS 18001 i poboljšanja provjeravanja i korektivnih aktivnosti u sustavu zaštite zdravlja i sigurnosti na radu se prihvaća. Statistička analiza svih zahtjeva norme povezanih s područjem provjeravanja i korektivnih aktivnosti u sustavu zaštite zdravlja i sigurnosti na radu pokazala je rast prosječne ocjene tijekom tri godine primjene. Na temelju tih podataka zaključuje se da primjena zahtjeva norme utječe na poboljšanje provjeravanja i korektivne aktivnosti u zaštiti zdravlja i sigurnosti na radu.

\section{$\mathrm{H}_{6}$ : Postoji povezanost između primjene zahtjeva norme OHSAS 18001 i ocjenjivanja sustava zaštite zdravlja i sigurnosti na radu}

U skupini od 6 pitanja u vezi s pregledom (ocjenom) koji provodi uprava, ispitanici su se izjašnjavali o primjeni navedenih zahtjevima norme kojima se poboljšava pregled (ocjena) koji provodi uprava. Time su utvrđeni podaci o primjeni ovih zahtjeva norme i poboljšanju performansi u vezi s pregledom (ocjenom) koji provodi uprava u poduzećima u prve 3 godine njihove primjene. Svi zahtjevi norme primjenjuju 
se, a njihova primjena ocijenjena je $u$ rasponu prosječnih ocjena od 3,57 do 4,86. Najnižom prosječnom ocjenom 3,57 ocijenjena je tvrdnja „pregled koji provodi uprava uključuje specifične teme koje zahtijeva norma", i to u prvoj godini primjene norme. Najvišom prosječnom ocjenom 4,86 u trećoj godini primjene norme ocijenjena je tvrdnja „pregled koji provodi uprava je dokumentiran“. Prema prikazanim rezultatima za svaki zahtjev norme utvrđen je rast prosječne ocjene njegove primjene, čime se zaključuje da primjena zahtjeva norme utječe na poboljšanje performansi zaštite zdravlja i sigurnosti na radu.

Ovisno o godini primjene zahtjeva, standardna devijacija prosječno se kreće u rasponu od 0,347 do 0,929. Koeficijent varijabilnosti populacije prema godinama primjene kreće se u rasponu od 0,12 do $0,863 \%$. Provedenim $\chi^{2}$ testom utvrđeno je da je razlika između frekvencija ocjena primjene zahtjeva u vezi s pregledom (ocjenom) koju provodi uprava statistički značajna, odnosno nije slučajna. Vjerojatnost slučajne pojave ovakvih rezultata manja je od 1 $\%$ (a kod nekih rezultata manja je od 0,1\%). Na temelju tih rezultata mogu se donositi statistički valjani zaključci.

Analizom ocjena tvrdnji za tri godine primjene sustava upravljanja utvrđeno je da se u ukupno 5 slučajeva ocjena tvrdnji u vezi s pregledom koji provodi uprava radi o odličnoj korelaciji varijabli (u rasponu od 0,76 do 1). Analizom ocjena tvrdnji za tri godine primjene sustava upravljanja utvrđeno je da se u ukupno 37 slučajeva ocjena tvrdnji u vezi s pregledom koji provodi uprava radi o dobroj korelaciji varijabli. Visina korelacije u navedenim slučajevima iznosi od 0,51 do 0,75. U ukupno 49 slučajeva ocjena tvrdnji u vezi s pregledom koji provodi uprava u rasponu je od 0,25 do 0,50 što potvrđuje da se radi o slaboj korelaciji varijabli u vezi s pregledom koji provodi uprava. $U$ ostalim slučajevima nije utvrđena korelacija navedenih varijabli. Na temelju prikazanih rezultata može se zaključiti da postoji povezanost između primjene zahtjeva norme OHSAS 18001 i ocjene zaštite zdravlja i sigurnosti na radu.
Hipoteza $\left(\mathrm{H}_{6}\right)$ - Postoji povezanost između primjene zahtjeva norme OHSAS 18001 i ocjenjivanja sustava zaštite zdravlja i sigurnosti na radu se prihvaća. Statistička analiza svih zahtjeva norme u vezi s ocjenom sustava zaštite zdravlja i sigurnosti na radu pokazala je rast prosječne ocjene tijekom tri godine primjene. Na osnovi ovih pokazatelja podataka zaključuje se da primjena zahtjeva norme utječe na poboljšanje ocjenjivanja sustava zaštite zdravlja i sigurnosti na radu.

Pregledom znanstvene literature nisu pronađena istraživanja čije je rezultate moguće direktno uspoređivati s rezultatima ovog istraživanja. Ostala provedena istraživanja ne bave se utvrđivanjem povezanosti primjene zahtjeva i performansi zaštite zdravlja i sigurnosti na radu, već pojedinim specifičnim segmentima primjene norme.

Tako se Vinodkumar i Bhasi (2011.) bave istraživanjem utjecaja certificiranih sustava upravljanja na odnos upravljanja sigurnošću i performansi sigurnosti u velikim nesrećama u kemijskoj industriji. Istraživanje je pokazalo da radnici u poduzećima koja su certificirana prema OHSAS 18001 značajno bolje doživljavaju sigurnosne varijable od radnika u poduzećima koja nisu certificirana različito. Ovo istraživanje ističe potrebu za OHSAS 18001 certifikatom zbog smanjenja nesreća, smanjenja odgovornosti te poboljšanja produktivnosti, sigurnosti i zdravlja radnika.

Istraživanje koje su proveli Hamidi, Omidvari i Meftahi (2012.) u tvornicama cementa u kojima se koriste sustavi kvalitete, okoliša i sigurnosti na radu ima retroaktivnu eksperimentalnu prirodu. Analizirani su pokazatelji za šest godina primjene sustava. Rezultati su pokazali značajnu razliku između različitih pokazatelja sigurnosti prije implementacije i nakon nje. Ispitivanje proizvodnih pokazatelja, kao što su povećanje stope produktivnosti i proizvodnje, ukazuje na utjecaj tih sustava na indekse proizvodnje i produktivnosti. Rezultati su pokazali da postojanje sigurnosnog sustava ne može osigurati povećanje produktivnosti. 
$\mathrm{Na}$ temelju provedenog istraživanja Desa i suradnici (2013.) razvili su strukturni model za proučavanje odnosa između OHSAS 18001 i provedbe mjera zaštite u automobilskoj industriji Malezije zbog poboljšanja performansi zaštite zdravlja i sigurnosti na radu. Autori smatraju da rezultati ovog istraživanja mogu koristiti u izradi modela i alata koji će se u praksi automobilske industrije moći koristiti kao vodič i referentno sredstvo za provedbu mjera zaštite. Na temelju razvijenog strukturnog modela autori u budućnosti namjeravaju provesti istraživanje odnosa performansi OHSAS 18001 i provedenih mjera zaštite zdravlja i sigurnosti na radu u automobilskoj industriji.

S ciljem sintetiziranja najboljih dostupnih dokaza o učincima sustava upravljanja zdravljem i sigurnošću na radu na zdravlje i sigurnost radnika i povezanosti s gospodarskim rezultatima Robson i suradnici (2007.) proveli su sustavni pregled dostupne literature. Rezultati studije bili su uglavnom pozitivni. Unatoč tim obećavajućim rezultatima, zaključeno je da količina dokaza nije bila dovoljna za preporuke u korist ili protiv sustava upravljanja zdravljem i sigurnošću na radu. Zaključeno je da je to zbog heterogenosti primijenjenih metoda u izvornim istraživanjima, malom broju studija, njihovoj općenito slaboj metodološkoj kvaliteti i nedostatku generalizacije od provedenih studija.

Na osnovi prikazanog pregleda zaključuje se da rezultate tih istraživanja nije moguće uspoređivati s rezultatima i zaključcima ovog istraživanja. Kako je to zaključeno i u studiji Robsona i suradnika (2007.), zbog nedostatka generalizacije provedenih istraživanja rezultate koji su dobiveni ovim istraživanjem nije moguće u potpunosti usporediti s drugim rezultatima. Rezultati istraživanja pojedinih područja u kontekstu su rezultata ovog istraživanja i ukazuju na zaključak da se međusobno potvrđuju.

\section{ZAKLJUČAK}

$\mathrm{Na}$ osnovi prikazanih rezultata istraživanja može se konstatirati da je potvrđena opća hipoteza te se potvrđuje da postoji povezanost između primjene zahtjeva norme OHSAS 18001 i performansi zaštite zdravlja i sigurnosti na radu. Primjena zahtjeva norme utječe na poboljšanje performansi zaštite zdravlja i sigurnosti na radu. Ovim istraživanjem postignuto je sljedeće:

- teorijski se pridonijelo sagledavanju značaja zahtjeva norme OHSAS 18001 u postupku poboljšanja performansi zaštite zdravlja i sigurnosti na radu

- znanstvenim metodama potvrđene su postavljene hipoteze o povezanosti primjene zahtjeva norme OHSAS 18001 i performansi zaštite zdravlja i sigurnosti na radu

- baza podataka prikupljenih istraživanjem s upitnikom za istraživanje može poslužiti kao osnova za daljnja istraživanja u raznim gospodarskim djelatnostima, ovisno o specifičnim opasnostima i rizicima

- praktičan značaj ogleda se u mogućnosti oblikovanja modela za primjenu zahtjeva norme OHSAS 18001 kojim se poboljšavaju performanse zaštite zdravlja i sigurnosti na radu

- na temelju rezultata istraživanja moguće je provesti aktivnosti u cilju povećanja stupnja implementiranosti zahtjeva norme i povećanja učinkovitosti primijenjenih zahtjeva, čime se može postići daljnje poboljšanje performansi zaštite zdravlja i sigurnosti na radu, kao i drugi pozitivni učinci društvenog, humanog i ekonomskog značaja.

S obzirom da se prepoznaje sve veći društveni značaj zaštite zdravlja i sigurnosti na radu, preporuka je da se izradi model za primjenu zahtjeva norme OHSAS 18001 kojim se poboljšavaju performanse zaštite zdravlja i sigurnosti na radu. Nakon izrade modela preporuča se provođenje istraživanja njegove primjene s usporednom analizom dobivenih rezultata. Na osnovi tako postavljenog modela moguća je kasnija prilagodba djelatnostima u kojima postoje specifične opasnosti i rizici.

\section{LITERATURA}

Arezes, P.M., Miguel, A.S.: The role of safety culture in safety performance measurement, Measuring Business Excellence, 7, 2003., 4, 20-28. 
British Standards Institution (BSI): Occupational Health and Safety Assessment Series, Occupational health and safety management systems - Requirements, OHSAS Project Group, 2007.

Desa, A.F.N.C, Habidin, N.F., Hibadullah, S.N., Fuzi, N.M., Zamri, F.I.M.: OHSAS 18001 Performances Efforts and OSHA Performance in Malaysian Automotive Industry, Journal of Environmental Science, Computer Science and Engineering \& Technology, 2, 2013., 2, 217-227.

Duijm, NJ,, Fiévez, C., Gerbec, M., Hauptmanns, U., Konstandinidou, M.: Management of health, safety and environment in process industry. Safety Science, 46, 2008., 6, 908-920.

Hamidi, N., Omidvari, M., Meftahi, M.: The effect of integrated management system on safety and productivity indices: Case study; Iranian cement industries, Safety Science, 50, 2012., 1, 1180-1189.

Hunjak, D., Palačić, D., Petričević, N.: Istraživanje stajališta o planiranju upravljanja sigurnošću, U: Zbornik radova $V$. Znanstveno-stručne konferencije $s$ međunarodnim sudjelovanjem 'Menadžment i sigurnost 2010', HDIS, Čakovec, 21-35, 2010.

Markič, M.: Kvaliteta života i rada kao sistemski aspekt zdravlja na radu, Rad i sigurnost, 7, 2003., 3, 199-222.

Palačić, D.: Sustavi upravljanja sigurnošću, IPROZ, Zagreb, 2011.

Palačić, D.: Sustav upravljanja zdravljem i sigurnošću na radu prema zahtjevima specifikacije OHSAS 18001:1999, Rad i sigurnost, 10, 2006., 1, 59-72.

Palačić, D.: The impact of implementation of the requirements of Standard No. OHSAS 18001:2007 to reduce the number of injuries at work and financial costs in the Republic of Croatia, International Journal of Occupational Safety and Ergonomics, Taylor \& Francis Online, 23, 2017., 2, DOI: 10.1080/10803548.2016.1211860
Petersen, D.: Analyzing Safety System Effectiveness, John Wiley and Sons, New York, 1996.

Petersen, D.: Safety management: A human approach, Des Plaines, ASSE; 2001.

Petersen, D.: Measurement of Safety Performance, Des Plaines, ASSE; 2005.

Powell, R.: The Measurement of Safety Performance, WorkSafe, West Perth, 2009.

Robson, L.S., Clarke, J.A., Cullen, K., Bielecky, A., Severin, C., Bigelow, P., Irvin, E., Culyer, A., Mahood, Q.: The effectiveness of occupational health and safety management system interventions: A systematic review, Safety Science, 45, 2007., 3, 329-353.

Tarrants, W.E.: The Measurement of Safety Performance, Garland, New York, 1980.

Vinodkumar, M.N., Bhasi, M.: A study on the impact of management system certification on safety management, Safety Science, 49, 2011., 1, 498-507.

Živković, S.: Motivacija za zaštitu na radu, Univerzitet u Nišu, Fakultet zaštite na radu u Nišu, Niš, 2008.

Živković, S., Palačić, D.: Upravljanje bezbednošću u poslovnim organizacijama u Srbiji $i$ Hrvatskoj - komparativna analiza, Univerzitet u Nišu, Fakultet zaštite na radu u Nišu, Niš, 2015.

Živković, S., Palačić, D., Petras, M.: Expected impact of application requirements of OHSAS 18001 and ISO 14001 on improvement of performances in occupational health, safety and environmental protection, U: Proceedings of 14th International Symposium on Quality: Quality against recession, Croatian Quality Managers Society, Rovinj, 245-255, 2013.

Žugaj, M., Dumičić, K., Dušak, V.: Temelji znanstvenoistraživačkog rada, Sveučilište u Zagrebu, Fakultet organizacije i informatike Varaždin, Varaždin, 1999. 


\section{EFFECTS OF OHSAS 18001 NORM IMPLEMENATON ON THE IMPROVEMENT IN SAFETY AND HEALTH AT WORK PERFORMANCES IN CROATIA}

SUMMARY: Presented in the paper are the results of the study focusing on the implementation of the OHSAS 18001 norm and the possible improvements in occupational safety and health in Croatia. The study relied on a questionnaire distributed to the subjects in the sample. The questionnaire was designed as a descriptive and analytical tool and was anonymous and voluntary. The sample was made up of the business organisations that have been implementing the OHSAS 18001 norm for at least three years. The objective was to determine whether the implementation of the OHSAS 18001 norm in effect improved occupational safety and health in the studied business organisations. In addition to the standard health and safety at work indicators, 124 items listed in the OHSAS 18001 norm are also regarded as health and safety performances at work. Conclusions are based on statistical analysis, with the correlation and regression analysis applied to the obtained results.

Key words: OHSAS 18001, performance, improvement, health and safety at work

Original scientific paper Received: 2017-08-23

Accepted: 2018-05-25 